\title{
Cases of cytomegalovirus retinitis in patients treated for cancer
}

Marium Jamaluddin Ahmad, Tengku Ain Kamalden, Nurliza Khaliddin, Tajunisah lqbal

UM Eye Research Centre, Department of Ophthalmology, University of Malaya, Kuala Lumpur, Malaysia

\section{Abstract}

Cytomegalovirus (CMV) retinitis is an opportunistic infection affecting immunocompromised patients. This case series describes 2 patients aged 19 and 10 years who were undergoing cancer treatment and were referred for complaints of worsening blurred vision. The retinal findings in the first patient showed multiple yellowish subretinal areas with haemorrhages, while in the second patient there was presence of frosted branch angiitis. Confirmation of diagnosis was done using PCR of vitreous samples and blood CMV levels. Both tested negative for HIV. Both received intravitreal and systemic ganciclovir. It is important for ophthalmologists to consider $\mathrm{CMV}$ retinitis in all patients with any form of immunosuppression.

Keywords: cancer treatment, cytomegalovirus retinitis, retina

Correspondence: Dr. Marium Binti Jamaluddin Ahmad, MBBS, UM Eye Research Centre, Department of Ophthalmology, University of Malaya Medical Centre, Lembah Pantai 59100, Kuala Lumpur, Malaysia.

E-mail: marium87mja@gmail.com 


\section{Kes-kes cytomegalovirus retinitis pada pesakit yang dirawat untuk kanser}

\section{Abstrak}

Retinitis Cytomegalovirus (CMV) adalah jangkitan oportunistik yang memberi jangkitan kepada pesakit kurang pertahanan imuniti badan. Siri kes ini merujuk kepada 2 pesakit berusia 19 dan 10 tahun yang menjalani rawatan kanser dan dirujuk dengan aduan penglihatan yang semakin kabur. Pemeriksaan pada pesakit pertama menunjukkan beberapa kawasan subretinal yang kekuningan dengan pendarahan. Sementara pada pesakit kedua terdapat kehadiran radang dan penyumbatan salur darah halus. Pengesahan diagnosis dilakukan menggunakan kaedah reaksi rangkaian polymerase (PCR) pada sampel vitreous dan tahap kehadiran CMV dalam darah. Kedua-dua kesdiuji negatif untuk kehadiran Human Immunodeficiency Virus (HIV). Kedua-duanya menerima rawatan ganciclovir secara intravitreal dan sistemik. Adalah penting bagi pakar oftalmologi untuk mempertimbangkan retinitis CMV dalam semua pesakit yang mengalami keadan pertahanan imuniti badan yang lemah.

Kata kunci: kurang pertahanan badan, sitomegalovirus, retinitis

\section{Introduction}

Cytomegalovirus (CMV) can cause severe disease in those who are immunocompromised. Infection with CMV is on the rise with the increase in organ transplant, immunosuppressive therapies, and human immunodeficiency virus (HIV)-infected patients. It is also one of the leading causes of birth defects. ${ }^{1}$ In this case series, we describe two cases of CMV retinitis in two young patients undergoing treatment for cancer.

\section{Case 1}

A 19-year-old Chinese man presented with left facial swelling in June 2017 and biopsy was done to confirm the diagnosis. He was diagnosed to have locally advanced and metastatic left maxillary rhabdomyosarcoma with cervical node, right pleural, and splenic node metastasis involving left orbit, gingiva, clivus, and left cheek. The patient had completed a course of VAID (ifosfamide, vincristine, actinomycin $\mathrm{D}$, doxorubicin) regime chemotherapy, was undergoing radiotherapy, and had a planned cycle of vincristine and cyclophosphamide. He presented to the eye clinic 


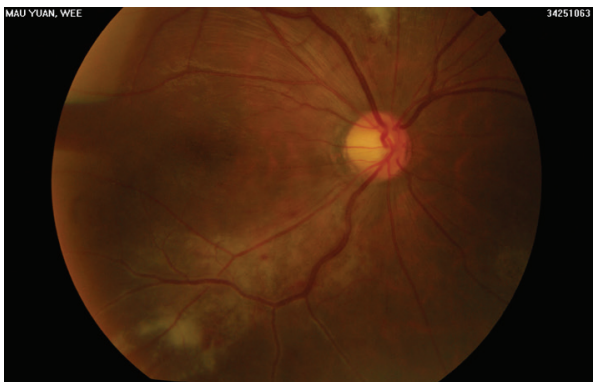

Fig. 1. Fundus image of the right eye showing areas of retinitis and retinal haemorrhages.

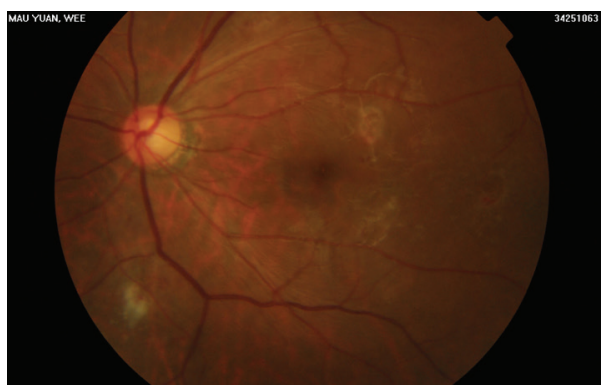

Fig. 2. Fundus image showing small area of retinitis.

complaining of blurred vision in the right eye $(R E)$ since completion of chemotherapy. There was no eye redness or eye pain. The symptoms were sudden in onset and gradually worsening. There was no preceding history of floaters or flashes of light.

On examination, his best-corrected visual acuity was $6 / 12$ in the RE and 6/9 in the left eye (LE). The anterior segment examination of both eyes was normal. The intraocular pressure was normal in both eyes (BE). The fundus examination in the RE showed scattered yellowish subretinal lesions at the retina and perivascular area with subretinal haemorrhages (Fig. 1). LE fundus examination revealed the same finding but less diffuse than in the RE (Fig. 2). There was no retinal necrosis at the time and no signs of retinal detachment. Optical coherence tomography (OCT) at the time showed macular swelling with subretinal fluid (SRF) in BE.

A vitreous tap was done for BE and sent for bacterial cultures and stains, as well as viral PCR which tested for CMV and varicella zoster. The viral PCR was positive for CMV with a viral load of 1.05 million IU/ml, while the bacterial cultures showed no growth. The patient was diagnosed with CMV retinitis. The patient was then treated with intravitreal (IVT) ganciclovir $2 \mathrm{mg} / 0.1 \mathrm{ml}$ and intravenous ganciclovir.

\section{Case 2}

A 10-year-old Chinese boy was referred by the paediatric oncology team for a complaint of blurred vision for three days in BE. He had been diagnosed with pre-B acute lymphoblastic leukaemia (ALL) and was on maintenance phase of chemotherapy. He had a history of hemophagocytic lymphohistiocytosis triggered by CMV four months prior to this complaint. He was previously treated with intravenous ganciclovir as well as oral valganciclovir $450 \mathrm{mg}$ BD. He was also on oral dexamethasone, oral methotrexate, Bactrim, imatinib, and mercaptopurine.

Vision in BE was $6 / 60$ with no relative afferent pupillary defect. BE showed fine keratic precipitates with anterior chamber cells of $3+$. The intraocular pressure was normal in BE. BE also showed generalised retinal haemorrhages with peri- 


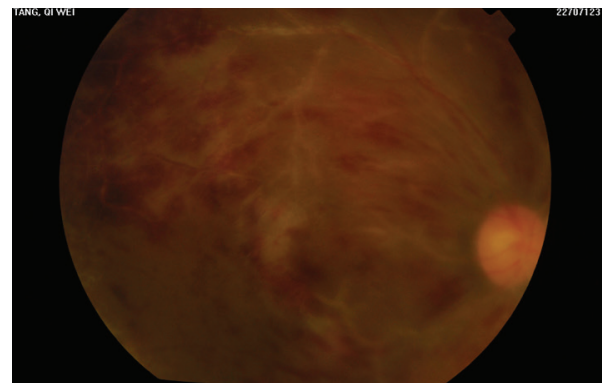

Fig. 3. Fundus image of the right eye showing retinal haemorrhages with retinitis along with frosted branch angiitis.

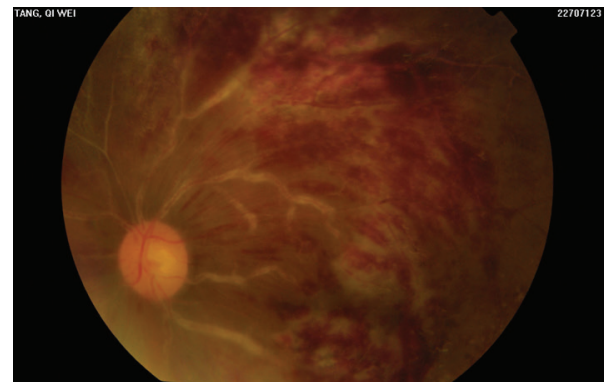

Fig. 4. Fundus image of the left eye showing retinal hemorrhages and retinitis along with frosted branch angiitis.

vasculitis and retinitis in all quadrants. The macula was oedematous and frosted branch angiitis present in all four quadrants (Figs. 3 and 4). Macular oedema was further confirmed by macular OCT macula.

The patient's blood was tested for CMV DNA with a value of 765 . He was then started on treatment for BE CMV retinitis. Started on gutt prednisolone acetate $1 \%$ every four hours and gutt atropine $1 \%$ TDS BE. He was then arranged for IVT ganciclovir $2 \mathrm{mg} / 0.1 \mathrm{ml}$ for BE and restarted on intravenous ganciclovir $190 \mathrm{mg}$ BD $(5 \mathrm{mg} / \mathrm{kg} /$ dose). His chemotherapy regime was withheld.

\section{Discussion}

Both cases described were undergoing treatment for two different types of cancers. Furthermore, both had a history of two or more admissions in the course of their illness for neutropenic sepsis, both being immunocompromised and prone to infections. Both tested negative for HIV. Within two to three months of diagnosis, both progressed to develop proliferative retinopathy and required pan-retinal photocoagulation.

There have been reported cases of CMV retinitis diagnosed in patients without HIV infection but immunocompromised due to other conditions. Rarely, this infection can occur in patients that have no evidence of immune insufficiency. The presentation in patients without HIV infection is variable and shows anterior segment inflammatory reaction. Most of the patients reported were on immunosuppressive medications like the both cases elaborated above. However, most reported cases had unilateral involvement, ${ }^{2}$ unlike the two cases presented in our report where BE were involved.

CMV retinitis occurs in patients who have failed to produce an immune response against the virus or in patients who once had CMV, but whose immune response is no longer effective due to immunosuppressive treatment, which was the case 
for both our patients undergoing chemotherapy for cancer. CMV retinitis produces direct cytopathic effects, giving rise to the pale necrotic retina with focal areas of haemorrhage that spread centrifugally along vascular arcades. Visual loss is either by direct involvement of the retinitis to the macula or optic disc, or due to retinal detachment. ${ }^{3}$

CMV retinitis is usually seen in advanced HIV infection and is rarely found in other immunocompromised patients. There has been emerging data on non-HIV related CMV retinitis associated with systemic steroid use. ${ }^{4} \mathrm{CMV}$ is a known infection in allogeneic transplantation recipients or those with T-cell deficiencies. Typically, CMV infection after stem cell transplantation gives rise to pneumonitis or enteritis, with retinitis being more common in those with HIV. ${ }^{5}$

CMV retinitis has been reported in a patient with long-standing rheumatoid arthritis who was being treated with immunosuppressive drugs, some of which included methotrexate, sulfasalazine, corticosteroids, cyclophosphamide, azathioprine, and finally anti-tumour necrosis factor- $\alpha$ antibodies (infliximab). ${ }^{6} \mathrm{CMV}$ retinitis has also been found in patients with limited immune dysfunction such as advanced aged, diabetes mellitus, and noncytotoxic immunotherapy, which would present with variable clinical features of intraocular inflammation and most also developed neovascularisation due to extensive retinal ischemia. ${ }^{7}$

\section{Conclusion}

CMV retinitis is a visually disabling disease and should be promptly treated to avoid visual loss. This infection is closely related to the patient's immune status and presentation may be variable.

\section{References}

1. Landolfo S, Gariglio M, Gribaudo G, Lembo D. The human cytomegalovirus. Pharmacol Ther. 2003;98(3):269-297.

2. Pathanapitoon K, Tesavibul N, Choopong P, et al. Clinical manifestations of cytomegalovirus-associated posterior uveitis and panuveitis in patients without human immunodeficiency virus infection. JAMA Ophthalmol. 2013;131(5):638-645.

3. Carmichael A. Cytomegalovirus and the eye. Eye. 2012;26(2):237.

4. Sloan D, Taegtmeyer M, Pearce I, Hart I, Miller A, Beeching N. Cytomegalovirus retinitis in the absence of HIV or immunosuppression. SAGE Publications Sage UK: London, England; 2008.

5. Goldberg SL, Pecora AL, Alter RS, et al. Unusual viral infections (progressive multifocal leukoencephalopathy and cytomegalovirus disease) after high-dose chemotherapy with autologous blood stem cell rescue and peritransplantation rituximab. Blood. 2002;99(4):1486-1488. 
6. Haerter G, Manfras BJ, de Jong-Hesse Y, et al. Cytomegalovirus retinitis in a patient treated with anti-tumor necrosis factor alpha antibody therapy for rheumatoid arthritis. Clin Infect Dis. 2004;39(9):e88-e94.

7. Schneider EW, Elner SG, van Kuijk FJ, et al. Chronic retinal necrosis: cytomegalovirus necrotizing retinitis associated with panretinal vasculopathy in non-HIV patients. Retina. 2013;33(9):1791-1799. 